Supplement of Web Ecol., 16, 51-58, 2016

http://www.web-ecol.net/16/51/2016/

doi:10.5194/we-16-51-2016-supplement

(C) Author(s) 2016. CC Attribution 3.0 License.

(c) (i)

Supplement of

\title{
Impacts of land-use intensification on litter decomposition in western Kenya
}

\section{G. H. Kagezi et al.}

Correspondence to: R. Brandl (brandlr@staff.uni-marburg.de)

The copyright of individual parts of the supplement might differ from the CC-BY 3.0 licence. 
Table S1. List of litter bag experiments conducted between September 2007 and July 2009 in the Kakamega area (Western Kenya) and in the Budongo Forest (Western Uganda). All experiments lasted for 5 weeks, except the experiment used to explore how long the bags should be exposed in the field. Except in very few cases, where we lost bags, all experiments are balanced in respect to mesh size and litter type. Due to logistic reasons we were not able to use ash mass loss. Therefore we cleaned our bags from material that entered the bags either by brushing or floating in water. We tested the influence of the cleaning procedure on our results (experiment 6), but found little impact.

\begin{tabular}{|c|c|c|c|c|c|c|c|}
\hline \# & Month & Year & Area & Land-use types & plots & $\begin{array}{c}\text { bags } \\
\text { within plots }\end{array}$ & Comments \\
\hline 1 & September to November & 2007 & Kakamega & $\begin{array}{l}\text { Primary forest } \\
\text { Secondary forest }\end{array}$ & $\begin{array}{l}5 \\
5\end{array}$ & $\begin{array}{l}20 \\
20\end{array}$ & $\begin{array}{l}\text { Experiment to explore how long bags should } \\
\text { be exposed in the field }\end{array}$ \\
\hline 2 & September, October & 2007 & Kakamega & Table 1 & 25 & 8 & $\begin{array}{l}\text { First experiment to evaluate the influence of } \\
\text { land-use intensification on mass loss }\end{array}$ \\
\hline 3 & December, January & $2007 / 08$ & Kakamega & Table 1 & 25 & 16 & $\begin{array}{l}\text { Second experiment to evaluate the influence } \\
\text { of land-use intensification on mass loss }\end{array}$ \\
\hline 4 & September, October & 2008 & Kakamega & $\begin{array}{l}\text { Primary forest } \\
\text { Farmland }\end{array}$ & 4 & 40 & $\begin{array}{l}\text { Experiment to evaluate mass loss of the two litter } \\
\text { types to document seasonal changes }\end{array}$ \\
\hline 5 & May, June & 2008 & Kakamega & Farmland & 20 & 16 & Decomposition in various cultivations \\
\hline 6 & June, July & 2008 & Kakamega & Primary forest & 1 & 40 & $\begin{array}{l}\text { Evaluation the effect of floating versus } \\
\text { brushing }\end{array}$ \\
\hline 8 & November, December & 2008 & Kakamega & $\begin{array}{l}\text { Primary forest } \\
\text { Farmland }\end{array}$ & 4 & 40 & $\begin{array}{l}\text { Second experiment to evaluate mass loss of the two litter } \\
\text { types to document seasonal changes }\end{array}$ \\
\hline 8 & January, February & 2009 & Kakamega & Forest & 11 & 20 & $\begin{array}{l}\text { Decomposition in fragments; only Croton; for a } \\
\text { map of fragments see Schleuning et al. } 2011\end{array}$ \\
\hline 9 & March to April & 2009 & Kakamega & $\begin{array}{l}\text { Primary forest, } \\
\text { Farmland }\end{array}$ & 4 & 49 & $\begin{array}{l}\text { Third experiment to evaluate the mass loss of the two litter } \\
\text { types to document seasonal changes }\end{array}$ \\
\hline 10 & June to July & 2009 & Budongo Forest & Primary forest & 6 & 20 & \\
\hline
\end{tabular}



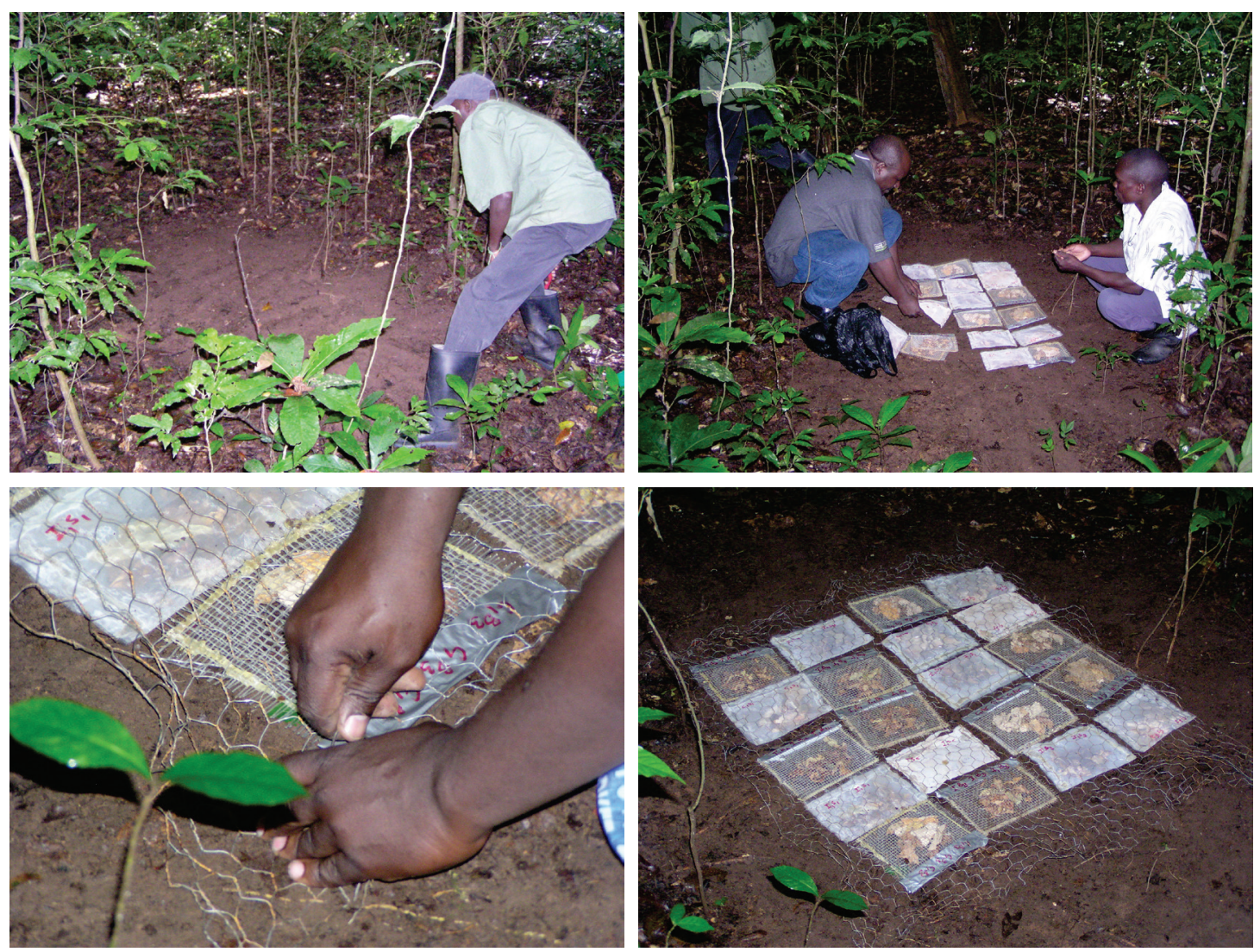

Figure S1. Photographs to illustrate our litter bags experiments (here Budongo Forest. Uganda; June 2009; experiment 10 in Table S1). We enclosed pre-weighed litter in litterbags and exposed the bags on the soil surface. Bags with large mesh size and small mesh size were either filled with Ipomoea leaves or Croton litter and we randomly arranged bags within the plots. Subsequently we covered the plot with chicken mesh wire to protect the litter bags from disturbance by animals. 


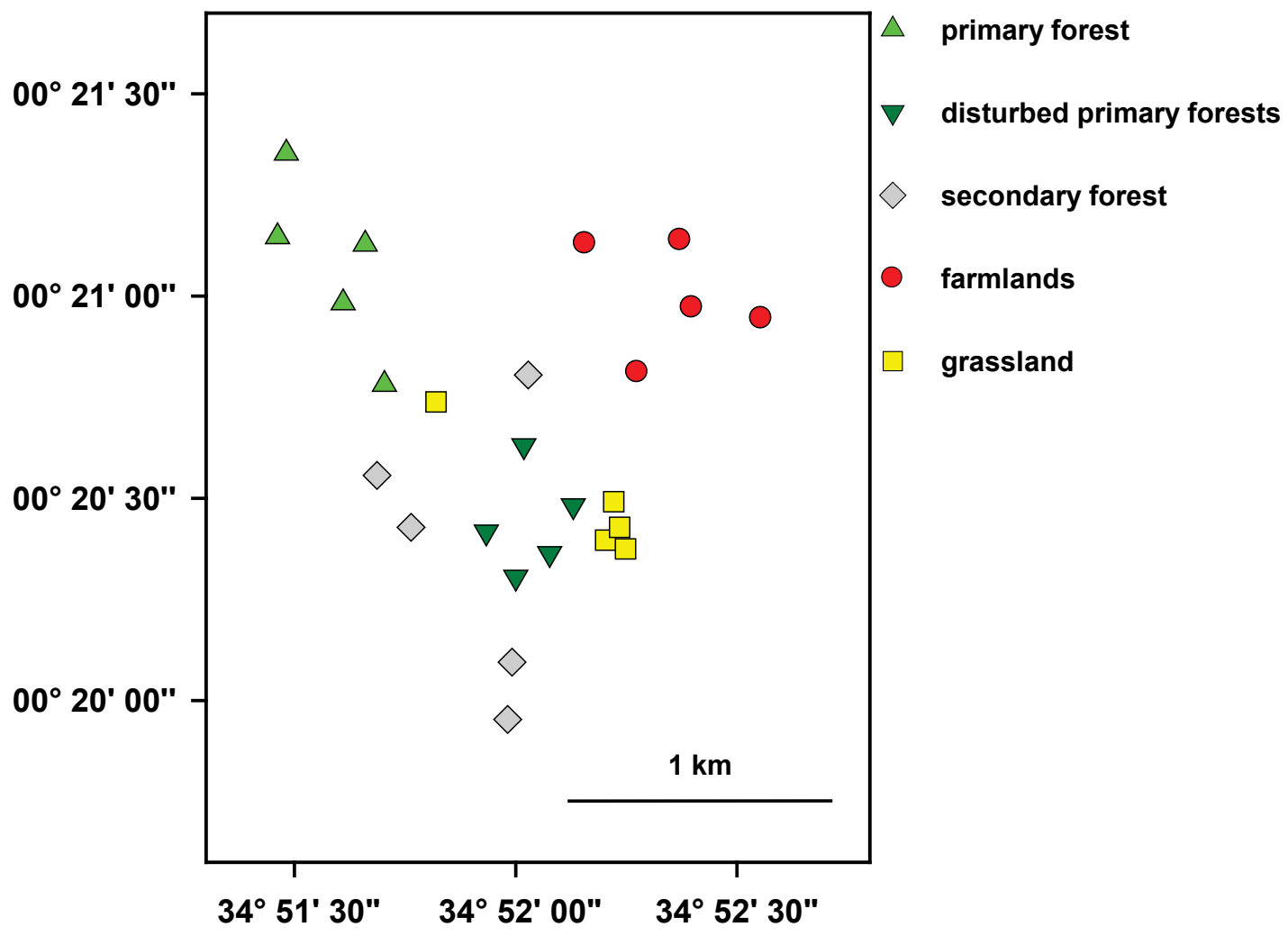

Figure S2. Location of the plots for estimating the influence of land use on decomposition. Note that the location of plots affected by the same land-use type are somehow spatially autocorrelated which inflates the degrees of freedom. 